\title{
HUBUNGAN PENGETAHUAN PENCEGAHAN DEMAM BERDARAH DENGAN INDEKS JENTIK
}

\author{
(The Correlation Knowledge of Dengue Fever Prevention with The Pinch Index)
}

Moh Alimansur, Bagus Prabowo

\section{ABSTRACT}

Dengue Fever disease in Indonesian called Demam Berdarah Dengue (DBD), concludes a disease caused by dengue virus which is until now it still become healty problem in society. DBD is an endemic which is encloses almost 300 states in the whole world. The aim of this research is, to know the correlation knowledge of dengue fever prevention with pinch index in Bandar Lor RT:23 RW:04 Mojoroto, Kediri.

The design used correlational, sampling method used is simple random sampling with sample total in 51 housemates in Bandar Lor RT:23 RW:04 Mojoroto, Kediri. The data of this research taken by using questionnaire and observation. After tabulating, the data which was analyzed by using cross test SPSS for Windows 17 with approx significant 0,824 .

The result of research shows good criteria 10 responders (19,6\%), fair 25 responders (49\%), enough 6 responders (11,8\%), and bad criteria criteria (19,6\%). Pinch index obtained is 64,7\%. While from the result of chi-square test uses SPSS for Windows 17 obtained there is no correlation of dengue fever prevention with the pinch index with coefisien 0,132 with significant level 0,824. So, we can conclude that no significant correlation between the prevention of dengue fever with pinch index.

Keyword: Prevention, Dengue Fever, Pinch Index

\section{Pendahuluan}

Penyakit Demam Berdarah Dengue (DBD) merupakan penyakit yang disebabkan oleh infeksi virus dengue yang sampai saat ini masih merupakan masalah kesehatan masyarakat.Di Indonesia penyakit ini merupakan penyakit endemik dengan ledakan kejadian luar biasa yang berlangsung pada periode-periode tertentu sehingga tak jarang menimbulkan kepanikan kepada masyarakat dan ketidaksiapan di berbagai sentra kesehatan maupun instansi terkait.Di Asia Tenggara termasuk Indonesia, epidemi DBD merupakan problem abadi dan penyebab utama morbiditas dan mortalitas pada anak-anak.Hasil studi epidemiologik menunjukkan bahwa penyakit ini terutama dijumpai pada umur antara 2-15 tahun dan tidak ditemukan perbedaan signifikan dalam kerentanan terhadap serangan DBD antar gender. Ke depan, peluang penyebaran DBD nampaknya masih terus meningkat sehubungan dengan kendala pemberantasan vector ( Aedes aegypti dan Aedes albopictus) dan mobilitas manusia yang semakin tinggi antar Negara. (Djoni Djunaedi, 2005).

DBD merupakan endemik yang melingkupi hampir 300 negara di seluruh dunia. Aedes aegypti merupakan faktor utama yang berkembang biak secara luas ke seluruh pulau. Keempat serotip (DEN 1 sampai 4) merupakan endemik terbanyak pada kota-kota besar di seluruh Negara. WHO mencatat kasus DBD di negaranegara Asia Tenggara meningkat dari 172.708 pada tahun 2009 menjadi 204.058 pada tahun 2010. (WHO South East Asian Region. www.searo.who.int.com).

Data dari Dinas Kesehatan (Dinkes) Kota Kediri, jumlah penderita DBD tahun 2010 bulan Januari 53 orang, Februari 167 orang, Maret 174, April 66, Mei 57, Juni 
46, Juli 19, Agustus 11, September 9, Oktober 4, Nopember 17. Total penderita adalah 623 orang, dengan jumlah meninggal 9 orang. (Data Dinas Kesehatan Kota Kediri).

Dari penelitian yang dilakukan mahasiswa Universitas Diponegoro jurusan epidemiologi di Desa Srodol Kulon didapatkan data, responden yang tidak memasang obat nyamuk pada siang dan sore hari $72 \%$, responden yang tidak memasang kelambu pada siang hari $89 \%$, responden yang tidak menggunakan bubuk abate pada tandon air bersih $61 \%$.

Penyakit ini ditunjukkan melalui munculnya demam tinggi terus menerus disertai adanya tanda perdarahan seperti ruam.Ruam demam berdarah memiliki ciri-ciri merah terang.Selain itu gejala lainnya adanya sakit perut, sakit kepala berat, sakit pada sendi (artralgia), sakit pada otot (mialgia).Sejumlah kecil kasus bisa menyebabkan syndrome shock dengue yang mempunyai tingkat kematian tinggi.

Sebenarnya penyakit ini dapat dicegah dan tidak perlu jatuh banyak korban apabila masyarakat mau memahami dan peduli akan bahaya penyakit ini. Karena belum adanya vaksin DBD, tindakan yang dapat dilakukan oleh keluarga adalah bersama-sama memberantas nyamuk aedes aegypti dengan cara membasmi jentik-jentik di tempat perindukannya, yaitu di genangan air, dengan cara $3 \mathrm{M}$, yaitu menguras (menaburkan bubuk abate), menutup tempat penampungan air, dan menimbun barang-barang bekas yang dapat menampung air. Sangat disayangkan jika penyakit ini meningkat kejadiannya dari waktu ke waktu hanya karena ketidaktahuan keluarga, sehingga mereka tidak siap siaga menghadapi ancaman penyakit yang setiap saat ada di hadapan kita.

\section{Metode}

Desain penelitian yang digunakan adalah desain penelitian deskriptif,
Populasi dalam penelitian ini adalah seluruh penghuni rumah/bangunan di Kelurahan Bandar Lor RT:23 RW:04 Kecamatan Mojoroto, Kota Kediri.Sampel dari penelitian ini adalah penghuni 51 rumah Penelitian ini menggunakan Simple Random Sampling. Variabel Independen: Pencegahan Demam Berdarah dengan indicator Melakukan 3M plus meliputi: menguras bak mandi minimal seminggu sekali, menutup rapat-rapat tempat penampungan air, menimbun barangbarang bekas yang dapat menampung air, mengganti air vas bunga/tanaman air seminggu sekali, menabur bubuk abate atau altosid pada tempat-tempat penampungan air, memelihara ikan di tempat-tempat penampungan air. Variabel Dependen: Indeks Jentik dengan indicator Angka Bebas Jentik (ABJ). Alat pengumpul data Dalam penelitian ini menggunakan lembar kuesioner dan observasi langsung. Selanjutnya untuk mengetahui hubungan antara pencegahan demam berdarah dengan indeks jentik dihitung dengan menggunakan uji statistik korelasi chi square dengan bantuan SPSS 17 for Windows,yaitu digunakan untuk mencari hubungan dan menguji hipotesis antara dua variabel.Tehnik ini digunakan untuk mengkorelasikan antara gejala yang berskala nominal dan gejala yang berskala ordinal.(Sugiyono, 2004).

Untuk kesimpulan ditolak atau diterima hipotesis dilakukan dengan memperhatikan angka signifikasi (tingkat kemaknaan). Apabila angka signifikasi hitung $\leq 0,05$ maka $\mathrm{H}_{1}$ diterima $\mathrm{H}_{0}$ ditolak. Apabila $>0,05$ maka $\mathrm{H}_{1}$ ditolak $\mathrm{H}_{0}$ diterima.

\section{Hasil}

Distribusi responden didapatkan dari 51 orang, distribusi Frekuensi Responden Berdasarkan Umur bahwa responden berumur 21 - 25 sejumlah 7 responden $(13,7 \%)$, yang berumur 26 - 30 sejumlah 6 responden $(11,8 \%)$, yang berumur $31-$ 35 sejumlah 5 responden $(9,8 \%)$, yang berumur 36 - 40 sejumlah 15 responden 
$(29,4 \%)$, yang berumur $41-45$ sejumlah 14 responden $(27,5 \%)$, sedangkan yang berumur 46 - 50 sejumlah 4 responden (7,8\%). Distribusi Frekuensi Responden Berdasarkan Pendidikan didapatkan bahwa dari latar belakang pendidikan sebagian besar berpendidikan SMP sejumlah 22 responden $(43,1 \%)$, kemudian SMA sejumlah 16 responden $(31,4 \%)$, SD sejumlah 9 responden $(17,7 \%)$, dan sebagian kecil berpendidikan Perguruan Tinggi sejumlah 4 responden (7,8\%). Distribusi Frekuensi Responden Berdasarkan Jenis Kelamin didapatkan bahwa responden pria sejumlah 35 responden $(68,6 \%)$, dan responden wanita sejumlah 16 responden $(31,4 \%)$.

Distribusi Frekuensi Responden Berdasarkan Upaya Pencegahan Demam Berdarah didapatkan bahwa kriteria Baik sejumlah 10 responden $(19,6 \%)$, kriteria Cukup Baik sejumlah 25 responden (49\%), kriteria Kurang Baik sejumlah 6 responden $(11,8 \%)$, dan kriteria Tidak Baik sejumlah 10 responden $(19,6 \%)$. Distribusi Frekuensi Responden Berdasarkan Keberadaan Jentik didapatkan bahwa rumah responden yang positif jentik sejumlah 18 rumah $(35,3 \%)$, sedangkan yang negatif jentik sejumlah 33 rumah (64,7\%). Hubungan Pengetahuan Pencegahan Demam Berdarah dengan Indeks Jentik Tabulasi Responden Berdasarkan Uji Silang Hubungan Pengetahuan Pencegahan Demam Berdarah dengan Indeks Jentik di Kelurahan Bandar Lor RT:23 RW:05 Kecamatan Mojoroto Kota Kediri

Tabel 1 : Tabel silang hubungan Pengetahuan pencegahan demam berdarah dengan indeks jentik.

\begin{tabular}{|c|c|c|c|c|c|c|}
\hline \multirow{3}{*}{ Pencegahan } & \multicolumn{4}{|c|}{ Indeks Jentik } & \multirow{2}{*}{\multicolumn{2}{|c|}{ Total }} \\
\hline & \multicolumn{2}{|c|}{ Negatif } & \multicolumn{2}{|c|}{ Positif } & & \\
\hline & $\sum$ & $\%$ & $\sum$ & $\%$ & $\sum$ & Persen \\
\hline Tidak Baik & 6 & 11,8 & 4 & 7,8 & 10 & 19,6 \\
\hline Kurang Baik & 3 & 5,9 & 3 & 5,9 & 6 & 11,8 \\
\hline Cukup Baik & 17 & 33,3 & 8 & 15,7 & 25 & 49,0 \\
\hline Baik & 7 & 13,7 & 3 & 5,9 & 10 & 19,6 \\
\hline \multicolumn{5}{|c|}{ Total } & \multicolumn{2}{|r|}{100} \\
\hline
\end{tabular}

Sumber : Data hasil penelitian
Berdasarkan tabel 1 di dapatkan bahwa responden yang melakukan pencegahan tidak baik sejumlah 10 responden (19,6\%), kurang baik 6 responden $(11,8 \%)$, cukup baik 25 responden (49\%), dan baik 10 responden $(19,6 \%)$. Berdasarkan hasil uji satistik didapatkan nilai alpha $0,824>0,05$, maka $\mathrm{H}_{0}$ diterima dan $\mathrm{H}_{1}$ ditolak.

Kesimpulan: Tidak ada hubungan pengetahuan pencegahan demam berdarah dengan indeks jentik. Keeratan hubungan termasuk dalam kategori sangat lemah (ditunjukkan oleh besarnya nilai contingency coefficient sebesar 0,132).

Interprestasi terhadap besarnya angka korelasi di dasarkan pada kekuatan korelasi. Untuk lebih lengkapnya dapat dilihat pada tabel sebagai berikut :

Tabel 4.8 Kekuatan Korelasi

\begin{tabular}{llll}
\hline No & Parameter & Nilai & Interprestasi \\
\hline 1 & Kekuatan & $0,00-0,199$ & Sangat lemah \\
& korelasi (r) & $0,20-0,399$ & Lemah \\
& & $0,40-0,599$ & Sedang \\
& & $0,60-0,799$ & Kuat \\
& & $0,80-1,000$ & Sangat kuat
\end{tabular}

(Sopiyudin, 2009:157)

\section{Pembahasan}

1. Pencegahan Demam Berdarah di Kelurahan Bandar Lor RT:23 RW:04 Kecamatan Mojoroto Kota Kediri.

Dari tabel 1 didapatkan bahwa sebagian besar responden upaya pencegahan demam berdarahkriterianya Cukup Baik yaitu sejumlah 25 responden (49\%), hal ini disebabkan bahwa sebagian besar responden berpendidikan SMP yaitu sejumlah 22 responden $(43,1 \%)$.

Menurut Newcomb dalam Notoatmodjo (2003), sikap merupakan kesiapan atau kesediaan untuk bertindak, yang menjadi predisposisi tindakan suatu perilaku, bukan pelaksanaan motif tertentu.

Dalam hal ini fungsi sikap adalah sebagai pendorong timbulnya minat. Sikap seseorang akan mempengaruhi minat dan mendorong untuk melakukan sesuatu (motivasi). Dibalik kecenderungan yang positif ini sebenarnya tidak semua 
orang memiliki pengetahuan dan sikap yang baik akan terwujud dalam bentuk perilaku nyata. Hal ini disebabkan banyak faktor yang mempengaruhi sikap dan perilaku.

Dari hasil tersebut faktor ekstern lebih menonjol dari pada faktor intern. Faktor ekstern yang meliputi lingkungan sekitar baik fisik maupun non fisik seperti iklim, manusia, sosial ekonomi, kebudayaan dan lain-lain mempengaruhi perilaku manusia itu sendiri untuk melakukan pencegahan penyakit demam berdarah dengue.

Menurut (Azwar, 1995), sikap memiliki tiga komponen yang membentuk struktur sikap, yaitu kognitif, afektif, dan konatif.

Komponen kognitif(cognitive).

Disebut juga perceptual, yang berisi kepercayaan yang berhubungan dengan persepsi individu terhadap objek sikap dengan apa yang dilihat dan diketahui, pandangan, keyakinan, pikiran, pengalaman pribadi, kebutuhan emosional, dan informasi dari orang lain. Sebagai contoh, seseorang tahu kesehatan itu sangat berharga jika menyadari sakit dan terasa nikmatnya sehat.

Komponen afektif (komponen emosional).Komponen ini menunjukkan dimensi emosional subjektif individu terhadap objek sikap, baik bersifat positif (rasa senang) maupun negatif (rasa tidak senang). Reaksi emosional banyak dipengaruhi oleh apa yang kita percayai sebagai sesuatu yang benar terhadap objek sikap tersebut.

Komponen konatif (komponen perilaku). Komponen ini merupakan predisposisi atau kecenderungan bertindak terhadap objek sikap yang dihadapinya . Faktor-faktor yang mempengaruhi pembentukan sikap adalah sebagai berikut pengalaman pribadi ,pengaruh orang lain yang dianggap penting, pengaruh kebudayaan, media massa, lembaga pendidikan dan lembaga agama, pengaruh faktor emosional (Azwar, 1995).

Dari hasil penelitian didapatkan usia responden yang sebagian besar $36-40$ tahun yaitu 15 responden $(29,4 \%)$ juga mempengaruhi dalam upaya pencegahan yang dilakukan, karena selain pengetahuan yang sudah banyak seiring dengan pengalaman yang didapat sehingga bisa mengubah sikap dan sudut pandang mengenai pentingnya pencegahan demam berdarah didukung pula dengan fisik yang masih kuat untuk melakukan kegiatan pencegahan demam berdarah itu sendiri.

Pada tabel 4.3 didapatkan sebagian besar berjenis kelamin pria sejumlah 35 responden $(68,6 \%)$, hal ini juga bisa mempengaruhi upaya pencegahan yang dilakukan masyarakat. Menurut sumber (www.undip.ac.id), faktor - faktor yang mempengaruhi pelaksanaan 3M diantaranya adalah usia dan jenis kelamin. Dari uraian di atas peneliti berpendapat bahwa jenis kelamin juga bisa mempengaruhi upaya pencegahan demam berdarah yang dilakukan masyarakat. Sudah kita ketahui bahwa pada umumnya pria lebih kuat dari wanita dalam hal kekuatan dan ketahanan fisik, hal ini tentunya akan berpengaruh dalam pelaksanaan kegiatan pencegahan demam berdarah yang dilakukan, misalnya untuk mengubur barang - barang bekas, membersihkan saluran air, menguras bak mandi, dan lain - lain pria akan lebih mampu melakukannya dibandingkan dengan wanita. Tak jarang oleh karena pelaksanaan kegiatan pencegahan demam berdarah tersebut tergolong berat dan menguras tenaga para wanita jadi malas dan asal - asalan dalam melakukannya bahkan mereka tidak mau melakukannya.

2. Indeks Jentik di Kelurahan Bandar Lor RT:23 RW:04 Kecamatan Mojoroto Kota Kediri.

Dari tabel 1 didapatkan bahwa sebagian kecil rumah responden yang positif jentik sejumlah 18 rumah $(35,3 \%)$, dan sebagian besar rumah responden yang negatif jentik sejumlah 33 rumah $(64,7 \%)$. Setelah dihitung menggunakan metode Angka Bebas Jentik (ABJ) hasilnya 
adalah $64,7 \%$ negatif jentik. Angka Bebas Jentik (ABJ) termasuk dalam kriteria baik adalah minimal harus $95 \%$ negatif jentik.

Dengue Hemoragic Fever atau DHF adalah DHF (Dengue hemoragic fever) atau lebih sering disebut Demam Berdarah Dengue adalah penyakit menular yamg disebabkan oleh virus Dengue, dan ditularkan melalui gigitan nyamuk aedes aegypti (Soegijanto, 2006 : 63)

Dengue Hemoragic Fever (DHF) adalah penyakit yang disebabkan oleh virus dengue sejenis virus yang tergolong arbovirus dan masuk ke dalam tubuh penderita melalui gigitan nyamuk aedes aegypti (betina).(eprints.undip.ac.id).

Indeks Jentik adalah suatu metode untuk menentukan kesehatan lingkungan dengan menentukan organisme apa yang ada/tampak dan berapa jumlahnya (www.undip.ac.id).

Angka Bebas Jentik (ABJ) lebih menggambarkan luasnya penyebaran nyamuk di suatu wilayah.Standar hasil penghitungan ABJ minimal harus 95\% yang artinya dari keseluruhan rumah yang diperiksa minimal harus $95 \%$ rumah negatif jentik.

Dari uraian tersebut peneliti berpendapat bahwa Angka Bebas Jentik di Kelurahan Bandar Lor RT:23 RW:04 Kecamatan Mojoroto Kota Kediri masih buruk yaitu masih kurang dari 95\% negatif jentik. Hal ini tentu harus mendapatkan perhatian dan penanganan yang lebih khususnya dari warga Kelurahan Bandar Lor RT:23 RW:04 Kecamatan Mojoroto Kota Kediri itu sendiri mengingat bahaya yang bisa ditimbulkan oleh penyakit demam berdarah yang disebarkan melalui gigitan nyamuk Aedes Aegypti.

\section{Hubungan Pencegahan Demam}

Berdarah dengan Indeks Jentik di Kelurahan Bandar Lor RT:23 RW:04 Kecamatan Mojoroto Kota Kediri.

Berdasarkan hasil penelitian pada tabel 1 tentang hubungan pencegahan demam berdarah dengan indeks jentik diketahui dari hasil uji statistic SPSS 17 for Windows menunjukkan nilai significancy 0,824 yang menunjukkan bahwa korelasi antara pengetahuan pencegahan demam berdarah dengan indeks jentik adalah tidak bermakna. Nilai Korelasi sebesar 0,132 menunjukkan bahwa arah korelasi negatif dengan kekuatan korelasi sangat lemah.

Pada tabel 1 responden yang memiliki pengetahuan pencegahan demam berdarah dengan baik namun masih didapati positif jentik ada 3 orang $(5,9 \%)$. Berdasarkan uraian di atas peneliti berpendapat bahwa antara hubungan pencegahan demam berdarah dengan indeks jentik tidaklah bermakna. Hal itu tentunya tidak terlepas dari faktor - faktor lain yang dapat mempengaruhi pelaksanaan pencegahan demam berdarah itu sendiri.

Menurut Newcomb dalam Notoatmodjo (2003), sikap merupakan kesiapan atau kesediaan untuk bertindak, yang menjadi presdiposisi tindakan suatu perilaku, bukan pelaksanaan motif tertentu . Menurut (Azwar, 1995), sikap memiliki tiga komponen yang membentuk struktur sikap, yaitu kognitif, afektif, dan konatif.

Komponen kognitif (cognitive). Disebut juga perceptual, yang berisi kepercayaan yang berhubungan dengan persepsi individu terhadap objek sikap dengan apa yang dilihat dan diketahui, pandangan, keyakinan, pikiran, pengalaman pribadi, kebutuhan emosional, dan informasi dari orang lain. Sebagai contoh, seseorang tahu kesehatan itu sangat berharga jika menyadari sakit dan terasa nikmatnya sehat.

Komponen afektif (komponen emosional).Komponen ini menunjukkan dimensi emosional subjektif individu terhadap objek sikap, baik bersifat positif (rasa senang) maupun negatif (rasa tidak senang). Reaksi emosional banyak dipengaruhi oleh apa yang kita percayai sebagai sesuatu yang benar terhadap objek sikap tersebut.

Komponen konatif (komponen perilaku). Komponen ini merupakan 
predisposisi atau kecenderungan bertindak terhadap objek sikap yang dihadapinya . Faktor-faktor yang mempengaruhi pembentukan sikap adalah sebagai berikut pengalaman pribadi ,pengaruh orang lain yang dianggap penting, pengaruh kebudayaan, media massa, lembaga pendidikan dan lembaga agama, pengaruh faktor emosional (Azwar, 1995).

Namun demikian jika dicermati ada juga responden yang memiliki pendidikan tinggi akan tetapi pencegahan tentang demam berdarahnya ataupun perilaku tidak tinggi. Hal ini merupakan penyimpangan atau tidak sesuai dengan konsep yang ada. Faktor penyebabnya adalah sikap dan tingkat pendidikan yang kurang.Hal ini mempengaruhi perilaku seseorang.

Pengetahuan atau pemahaman tentang sesuatu objek juga mengandung dua aspek yaitu aspek positif dan aspek negatif. Kedua aspek inilah yang akhirnya akan menentukan sikap seseorang terhadap objek tertentu. Semakin banyak aspek positif dari objek yang diketahui, akan menumbuhkan sikap makin positif terhadap objek tersebut.

Hal ini berarti tanpa sikap yang positif (mendukung) maka tidak akan terbentuk perilaku atau tindakan nyata dalam melaksanakan pencegahan penyakit demam berdarah dengue.

Kesimpulan dan saran

1. Dari hasil penelitian didapatkan bahwa sebagian besar responden pengetahuan pencegahan demam berdarahnya cukup baik yaitu sejumlah 25 responden (49\%).

2. Dari hasil penelitiandidapatkan bahwa sebagian besar rumah responden setelah dihitung menggunakan metode Angka Bebas Jentik (ABJ) hasilnya adalah $64,7 \%$ negatif jentik. Menurut teori dikatakanbahwa Angka Bebas Jentik (ABJ) termasuk dalam kriteria baik adalah minimal harus $95 \%$ negatif jentik.
3. Berdasarkan hasil penelitian tentang hubungan pencegahan demam berdarah dengan indeks jentik diketahui dari hasil uji statistic SPSS 17 for Windows menunjukkan nilai significancy 0,824 yang menunjukkan bahwa korelasi antara pencegahan demam berdarah dengan indeks jentik adalah tidak bermakna. Nilai Korelasi sebesar 0,132 menunjukkan bahwa arah korelasi negatif dengan kekuatan korelasi sangat lemah.

Saran

Hasil penelitian dapat dimanfaatkan oleh masyarakat sebagai masukan untuk lebih memperhatikan lingkungan fisik, lingkungan biologi dan lingkungan sosial serta kegiatan Pemberantasan Sarang Nyamuk sebagai upaya menurunkan angka kejadian DBD.

\section{DAFTAR PUSTAKA}

Alimul, Aziz, A. 2007. Riset Keperawatan Dan Teknik Penulisan Ilmiah. Jakarta :Salemba Medika.

Arikunto, S. 2006 dan 2002. Prosedur Penelitian. Ed. 5. Jakarta : Rineka Cipta. Hal 247-329.

Dinkes. 2010. Pencegahan Demam Berdarah dengan 3M.Tangerang : @www.dinkeskabtangerang.go.id. Diakses tanggal 2 Januari 2011, pukul 20.15 WIB.

Djunaedi, Djoni. 2006. Demam Berdarah. Malang : UMM Press.

Jurnal Undip. 2009. Upaya masyarakat dalam pencegahan DBD. Semarang : @ www.undip.ac.id. Diakses tanggal 2 Januari 2011, pukul 20.30 WIB.

Jurnal Undip. 2008. Indeks Jentik. Semarang : @www.undip.ac.id. Diakses tanggal 6 Januari 2011, pukul 09.30 WIB.

Jurnal Undip. 2009. Konsep Demam Berdarah. Semarang : @www.undip.ac.id. Diakses tanggal 2 Januari 2011, pukul 19.45 WIB. 
Jurnal Undip. 2009. Cara penularan penyakit DBD. Semarang : @www.undip.ac.id. Diakses tanggal 6 Januari 2011, pukul 10.00 WIB.

Nursalam. 2003. Konsep dan Penerapan Metodologi Penelitian Ilmu Keperawatan $(183,184)$. Surabaya : Salemba medika.

Nursalam dan Pariana Siti. 2001. Metodologi RisetKeperawatan. Jakarta : CV. Sagung Seto.
Notoatmojo, Soekidjo. 2005. Metodologi penelitian kesehatan. Jakarta : Rineka cipta.

Notoatmodjo, S. (2003). Metodologi Penelitian Kesehatan. Jakarta : Rineka Cipta. Hal 43-92.

Sugiyono.2002. Statistik Nonparametris. Bandung : CV Alfabeta.

WHO. 1999. Demam Berdarah Dengue. Jakarta : EGC. 